\title{
MENINGKATKAN MOTIVASI BELAJAR SISWA KELAS VII-BSMP \\ PADA PELAJARAN PENDIDIKAN AGAMA KRISTEN MELALUI \\ PENERAPAN PEMBELAJARAN KOOPERATIF TIPE JIGSAW DI NEGERI 1 STABAT
}

\author{
Dina Sembiring \\ Surel : dra.dina.sembiring@gmail.com
}

\begin{abstract}
ABSTRAK
Sudah menjadi rahasia umum bahwa setiap terjadi proses pembelajaran di kelas ada kecenderungan bahwa siswa sangat tidak aktif atau pasif dalam menanggapi proses pembelajaran. Hal ini disebabkan oleh banyak faktor, baik karena kurang menariknya cara guru menjelaskan, jenuhnya siswa karena terlalu panjang guru menerangkan, atau disebabkan kurang dimengertinya permasalahan yang dijelaskan. Penerapan pembelajaran kooperatif tipe Jigsaw dapat meningkatkan motivasi belajar siswa pada mata pelajaran Pendidikan Agama Kristen kelas di SMP N 1 Stabat kabupaten Langkat. Dengan metode ini diharapkan motivasi belajar siswa bisa meningkat. Dan setelah penelitian ini ternyata hasil yang di dapat dari penerapan metode pembelajaran kooperatif tipe Jigsaw dapat membuat pelajaran Agama Kristen yang terkesan menjemukan dapat menjadi lebih menyenangkan
\end{abstract}

Kata Kunci: Jigsaw, Kooperatif

\section{PENDAHULUAN}

Pengalaman

kerap

mengajarkan kepada kita bahwa apa yang kita ketahui (pengetahuan dalam ranah kognitif) tidak selalu membuat kita berhasil dalam hidup. Tetapi kemampuan, keuletan, dan kecekatan kita mencerna dan mengaplikasikan ilmu tersebut dalam hidup nyata itulah yang akan membuat hidup kita menjadi lebih berarti dan bermutu. Ini berarti kita perlu memiliki berbagai kecerdasan agar hidup kita berhasil. Bahkan secara agak ekstrim Cooper kecerdasan pada ranah kognitif (IQ) hanya memberi kontribusi sebesar 4$10 \%$ untuk keberhasilan hidup seseorang. Artinya $90 \quad \%$ keberhasilan seseorang dalam hidupnya ditentukan oleh kemampuannya mencerna dan mengaplikasikan dalam hidup nyata.

Demikian juga dalam hidup keagamaan, orang tidak menjadi selamat karena pengetahuan yang dimilikinya. Orang yang beriman diharapkan dapat menginterpretasikan dan mengaplikasikan imannya dalam hidup sehari-hari. Karena itu pendidikan agama kristen di sekolah hendaknya juga memungkinkan siswa memiliki kompetensi untuk mencernakan dan mengaplikasikan pengetahuan iman dalam hidupnya sehari-hari.

Pendidikan di sekolah seyogyanya memberi peluang yang sebesar-besarnya kepada setiap peserta didik untuk mengembangkan potensi dirinya. Pendidikan di 

sekolah juga harus menghasilkan siswa yang memiliki semangat untuk terus belajar seumur hidup (longlife education), penuh rasa ingin tahu dan keinginan menambah ilmu dan ketrampilan yang berguna untuk kehidupannya. Salah satu kunci untuk mewujudkan pendidikan yang demikian adalah adanya motivasi yang tinggi dan terpelihara dalam diri peserta didik.

Namun suasana pembelajaran yang ideal seperti di atas; anak memiliki motivasi belajar yang tinggi dan tetap terpelihara tidaklah setiap saat dapat kita alami. Kita berharap anak dapat mencapai prestasi secara optimal, namun yang kita jumpai adalah anak dengan prestasi dan semangat belajar yang rendah. Kita berharap anak akan terlibat secara aktif dalam pembelajaran, namun mereka bersikap pasif dan kurang terlibat dalam proses pembelajaran. Kita berharap anak didik akan berkembang menjadi anak-anak yang mandiri, namun setiap saat kita masih menjumpai anak yang tidak mengerjakan tugas rumah yang diberikan. Situasi-situasi seperti di atas tidak terkecuali kami alami dalam proses pendidikan agama kristen.

Rendahnya motivasi belajar siswa merupakan masalah yang perlu disikapi secara serius oleh seorang guru dalam proses pendidikan di sekolah. Kami merasa prihatin terhadap permasalahan tersebut. Berdasarkan keprihatinan terhadap masalah itulah kami merencanakan suatu tindakan untuk meningkatkan motivasi belajar siswa khususnya dalam Pendidikan Agama Kristen di SMP Negeri 1 Stabat. Upaya meningkatkan motivasi belajar siswa khususnya dalam Pendidikan Agama Kristen tersebut kami lakukan dengan menerapkan model permbelajaran kooperatif (Cooperative learning) tipe Jigsaw. Penerapan model pembelajaran kooperatif (Cooperative Learning) merupakan hasil refleksi terhadap proses pendidikan yang telah berlangsung selama ini. Sekolah cenderung menjadi arena persaingan. Mulai dari awal masa pendidikan di sekolah, seorang anak belajar dalam suasana kompetisi dan harus berjuang keras memenangkan kompetisi untuk naik kelas atau lulus ujian. salah satu falsafah yang mendasari pola pendidikan kompetitif adalah teori evolusi Darwin, yang menyatakan siapa yang kuat dialah yang akan menang dan bertahan dalam kehidupan. Prinsip survival of the fittest kerap tercermin dalam pendidikan di sekolah. Hadiah dan penghargaan selalu diberikan kepada sang juara, yaitu mereka yang mampu mengalahkan yang lain. Secara negatif model pembelajaran kompetitif hanya akan melahirkan semangat individualisme dalam diri peserta didik.

Padahal manusia sejak kelahirannya di dunia ini telah diajarkan bahwa dirinya adalah mahluk social. Kerja sama merupakan kebutuhan yang sangat 
penting bagi kelangsungan hidup manusia. Seorang individu hanya akan semakin menyadari individualitasnya (kepribadiannya yang unik) justru dalam interaksinya yang semakin intens terhadap lingkungannya.

Dalam buku Silabus

Pendidikan Agama Kristen untuk SMP bahwa, Pendidikan agama di SMP dimaksudkan untuk membantu siswa menjadi manusia yang beriman dan bertakwa kepada Tuhan Yang maha Esa dan berakhlak mulia serta peningkatan potensi kehidupan spiritual. Akhlak mulia mencakup etika, budi pekerti, dan moral sebagai perwujudan dari pendidikan Agama. Peningkatan potensi kehidupan spiritual mencakup pengenalan, pemahaman, dan penanaman nilainilai keagamaan dalam kehidupan individual maupun kolektif kemasyarakatan. Peningkatan potensi kehidupan spiritual tersebut pada akhirnya bertujuan pada optimalisasi berbagai potensi manusia yang aktualisasinya mencerminkan harkat dan martabatnya sebagai mahluk Tuhan.

\section{METODE PENELITIAN}

Penelitian Tindakan Kelas ini dilaksanakan dalam dua siklus. Setiap siklus tindakan pembelajaran menerapkan model atau pendekatan kooperatif (Cooperative Learning) tipe Jigsaw. Penggunaan model atau pendekatan kooperatif (Cooperative Learning) tipe Jigsaw ini bertujuan untuk meningkatkan motivasi belajar yang salah satu indikatornya dapat dilihat pada meningkatnya prestasi belajar siswa.

\section{HASIL PENELITIAN DAN PEMBAHASAN}

Kemajuan Aktivitas Siswa dalam PBM.

\begin{tabular}{|c|c|c|c|c|c|}
\hline \multirow{2}{*}{$\mathrm{N}_{0}$} & \multirow{2}{*}{ Item Penilaian } & \multirow{2}{*}{$\begin{array}{l}\text { Skor } \\
\text { Ideal }\end{array}$} & \multicolumn{2}{|c|}{ Skor yang dicapai } & \multirow{2}{*}{$\begin{array}{l}\text { Kemajuan yg } \\
\text { dicapai (\%) }\end{array}$} \\
\hline & & & Pertemuan I & Pertemuan II & \\
\hline 1 & Minat & 24 & $12(50 \%)$ & $17(70,8 \%)$ & $20,8 \%$ \\
\hline 2 & Perhatian & 24 & $12(50 \%)$ & $20(83 \%)$ & $33 \%$ \\
\hline 3 & Partisipasi & 24 & $13(54 \%)$ & $18(75 \%)$ & $25 \%$ \\
\hline 4 & Presentasi & 24 & $12(50 \%)$ & $18(75 \%)$ & $25 \%$ \\
\hline
\end{tabular}

Hasil observasi terhadap aktivitas guru dalam proses belajar mengajar mengalami perkembangan yang cukup baik pada siklus pertama ini. Pada pertemuan pembelajaran pertama aktivitas guru dalam memotivasi siswa masih tergolong rendah. Skor penilaian yang dicapai baru 30 dari sekor maksimal 44 . Dengan kata lain performance guru dalam pembelajaranbaru mencapai $68 \%$. Hal ini disebabkan perhatian guru masih lebih banyak pada upaya menjelaskan metode pembelajaran kooperatif tipe jigsaw yang dirasakan masih merupakan hal baru bagi siswa.

Input yang diberikan secara obyektif oleh rekan sejawat ternyata memberikan kontribusi yang sangat besar bagi usaha guru untuk meningkatkan kinerjanya. 
Pada pertemuan kedua skor penilaian/pengamatan mencapai 37 dari skor maksimal 44 atau mencapai $84 \%$, mengalami kemajuan sebesar $16 \%$ merupakan sebuah kemajuan yang cukup baik.

\begin{tabular}{|c|c|c|c|c|c|}
\hline \multirow{2}{*}{$\mathrm{N}_{0}$} & \multirow{2}{*}{ Item Penilaian } & \multirow{2}{*}{$\begin{array}{l}\text { Skor } \\
\text { Ideal }\end{array}$} & \multicolumn{2}{|c|}{ Skor yang dicapai } & \multirow{2}{*}{$\begin{array}{l}\text { Kemajuan yg } \\
\text { dicapai }(\%)\end{array}$} \\
\hline & & & Siklus I & Siklus II & \\
\hline 1 & Minat & 24 & $17(70,8 \%)$ & $20(83 \%)$ & $20,8 \%$ \\
\hline 2 & Perhatian & 24 & $20(83 \%)$ & $20(83 \%)$ & $33 \%$ \\
\hline 3 & Partisipasi & 24 & $18(75 \%)$ & $21(87,5 \%)$ & $25 \%$ \\
\hline 4 & Presentasi & 24 & $18(75 \%)$ & $20(83 \%)$ & $25 \%$ \\
\hline
\end{tabular}

Hasil observasi terhadap aktivitas guru dalam proses belajar mengajar pada siklus kedua ini lebih baik dibadungkan pada siklus pertama. Skor penilaian yang dicapai mengalami peningkatan dari 30 hingga 40 dari sekor maksimal 44. Dengan kata lain performance guru dalam pembelajaran pada siklus kedua ini mengalami peningkatan 22 $\%$.

\section{Pembahasan}

Peningkatan significant yang dicapai oleh guru tersebut tentu tidak terluput berkat interksi yang semakin intensif dengan siswa dalam proses pembelajaran. Dengan demikian guru lebih memahami karaktristik siswa dengan berbagai permasalahan belajar yang mereka alami. Selain itu input yang diberikan secara obyektif oleh rekan sejawat juga memberikan kontribusi yang sangat besar bagi usaha guru untuk meningkatkan kinerjanya.

\section{SIMPULAN}

Berdasarkan hasil penelitian tindakan kelas yang telah dilakukan maka dapat disimpulkan sebagai berikut:

a. Penerapan pembelajaran kooperatif tipe Jigsaw dapat meningkatkan motivasi belajar siswa pada mata pelajaran Pendidikan Agama Kristen kelas di SMP Negeri 1 Stabat kabupaten Langkat.

b. Meningkatnya motivasi siswa dapat dilihat dari semakin tingginya keterlibatan siswa dalam aktivitas pembelajaran dan terciptanya suasana pembelajaran yang lebih kooperatif. Suasana pembelajaran yang kondusif berkat metode pembelajaran yang kooperatif memungkinkan siswa untuk menentukan sendiri langkah-langkah dalam mencari penyelesaian masalah-masalah yang timbul dalam pembelajaran, mencerna informasi dan mengkonstruksi sendiri pengetahuan sehingga prestasi siswa dengan sendirinya juga meningkat.

c. Penerapan metode pembelajaran kooperatif tipe Jigsaw dapat membuat pelajaran Agama Kristen yang terkesan menjemukan dapat menjadi lebih menyenangkan. 
Dina Sembiring : Meningkatkan Motivasi ....

DAFTAR RUJUKAN

Ali, Mohammad, Dr., Prof, M.Pd, MA. 2007. Ilmu dan Aplikasi Pendidikan. Bandung: PT. Imperial Bhakti Utama (PT. INTIMA).

Arikunto, Suharsimi, Prof, (et.al). 2010. Penelitian Tindakan Kelas. Jakarta: PT. Bumi Aksara.

Harsanto, Radno, Drs, M.Si. 2007. Pengelolaan Kelas yang Dinamis. Yogyakarta: Penerbit Kanisius.
Kunandar, S.Pd, M.Si. 2009. Langkah Mudah Penelitian Tindakan Kelas Sebagai Pengembangan Pprofesi Guru. Jakarta: Rajawali Pers.

Komisi Kateketik KWI. 2007. Menjadi Murid Yesus Pendidikan Agama Kristen untuk Sekolah Dasar Buku Guru. Yogyakarta: Penerbit Kanisius.

Wiraatmadja, Rochiati, Dr, Prof. 2008. Metode Penelitian Tindakan Kelas. Bandung: PT. Remaja Rosdakarya. 